\title{
v-Myb of E26 leukemia virus up-regulates bcl-2 and suppresses apoptosis in myeloid cells
}

\author{
Jonathan Frampton, ${ }^{1}$ Torbjörn Ramqvist, and Thomas Graf \\ European Molecular Biology Laboratory, D-69117 Heidelberg, Germany
}

\begin{abstract}
Many oncogenes have been shown to be deregulated transcription factors, yet direct target genes mediating cell transformation remain elusive. Here we describe such a target for $\mathbf{v}-M y b$ by exploiting a temperature-sensitive mutant of the E26 avian leukemia virus encoding Myb-Ets. Myeloblasts transformed by the mutant differentiate into macrophages or die by apoptosis when shifted to the nonpermissive temperature as a result of inactivation of $\mathbf{v}-\mathrm{Myb}$. During this process mRNA of the antiapoptotic oncoprotein Bcl-2 is down-regulated with kinetics similar to those of $\mathrm{Mim}-1$, a differentiation-related protein whose expression is directly regulated by Myb. Forced expression of $b c l-2$ rescues the cells from apoptosis, without preventing either their withdrawal from the cell cycle or their differentiation. v-Myb appears to act directly on the bcl-2 gene, because a $b c l-2$ promoter-driven reporter is activated by Myb-Ets and v-Myb-VP16 and requires intact Myb binding sites within the promoter. Surprisingly, inactivation of $\mathbf{v}-M y b$ in multipotent progenitors transformed by E26 virus does not induce apoptosis, indicating that bcl-2 regulation by the oncoprotein is required for the transformation of some cell types but not others.
\end{abstract}

[Key Words: Myb; leukemia; myeloid cell transformation; programmed cell death]

Received July 3, 1996; revised version accepted September 11, 1996.

The c-Myb protein, which contains three homeo domain-related DNA binding repeats, acts as a sequencespecific transcription factor (for review, see Lüscher and Eisenman 1990; Graf 1992). Inactivation experiments in mice (Mucenski et al. 1991) have shown that it plays a central role in definitive hematopoiesis. Also, its abundant expression in various immature blood cell types suggests that it affects differentiation and/or growth control in a number of different lineages (Westin et al. 1982; Kastan et al. 1989). Myb was identified originally by its occurrence in two acute avian leukemia retrovirus strains, E26 and AMV (Roussel et al. 1979). In the E26 strain, the v-Myb oncoprotein is fused to v-Ets, and this is a prerequisite for the high leukemogenic capacity of the virus (Metz and Graf 1991a). The infection of yolk sac cells from 2-day-old embryos with E26 virus results in the transformation (i.e., induction of proliferation) of two different cell types: myeloblasts, which can differentiate into both macrophages and neutrophil granulocytes; and Myb-Ets-transformed progenitors (MEPs), which have the potential to differentiate into thrombocytes, erythrocytes, eosinophils, and myeloblasts /Graf et al. 1992; Frampton et al. 1995). v-Myb alone is sufficient to transform myeloid cells, because both E26 mutants lacking the ets oncogene and the AMV strain are

${ }^{1}$ Corresponding author. Present address: Institute of Molecular Medicine, John Radcliffe Hospital, Headington, Oxford OX3 9DU, UK. capable of transforming cells of this lineage (for review, see Lüscher and Eisenman 1990; Graf 1992).

In an attempt to unravel the mechanism of transformation by the E26 virus, our laboratory has developed, through the use of biological screens, a number of temperature-sensitive $(t s)$ mutants with lesions in $\mathrm{v}-\mathrm{Myb}$. The mutation in the prototypic mutant, $t s 21$, corresponds to a threonine to arginine substitution in the third repeat (R3) of the Myb DNA-binding domain (Frykberg et al. 1988). It completely abolishes specific $\mathrm{Myb}$ DNA binding activity at $42^{\circ} \mathrm{C}$, the nonpermissive temperature (Frampton et al. 1995). ts21-transformed myeloblasts shifted to $42^{\circ} \mathrm{C}$ are arrested in their growth and differentiate into macrophages (Beug et al. 1984, 1987), whereas under the same conditions ts21-transformed MEPs are not growth-arrested and differentiate into thrombocytes (Frampton et al. 1995). Using a differential screening technique to search for downstream targets we have identified mim-1 as a direct target gene of Myb (Ness et al. 1989). However, because Mim-1 is a protein expressed in the granules of neutrophil granulocytes, it probably plays no role in establishing the transformed phenotype. A number of additional direct $\mathrm{v}-\mathrm{Myb}$ targets have been identified recently, but none could be linked to the transforming capacity of the oncoprotein (for review, see Frampton et al. 1996). Targets relevant for transformation by v-Myb (as well as for other transcription factor-type oncogenes), therefore, remain to be identified. 
Here we show that $\mathrm{v}-\mathrm{Myb}$ acts as a survival factor for myeloid cells by directly up-regulating the antiapoptotic $b c l-2$ gene, making this gene a first target relevant to transformation by the oncogene.

\section{Results}

Myeloblasts transformed by ts21 E26 undergo apoptosis when shifted to $42^{\circ} \mathrm{C}$

When ts 21 E26-transformed myeloblasts were shifted from $37^{\circ} \mathrm{C}$ (the permissive temperature) to $42^{\circ} \mathrm{C}$ (the nonpermissive temperature) for 2 days we observed not only differentiating cells but also cell death (Beug et al. 1984, 1987; J. Frampton and T. Graf, unpubl.). This prompted us to ask whether the cells had died by apoptosis. Indeed, ts 21 myeloblasts shifted to $42^{\circ} \mathrm{C}$ for $60 \mathrm{hr}$ exhibited fragmented nuclei and chromatin condensations (Fig. 1A)
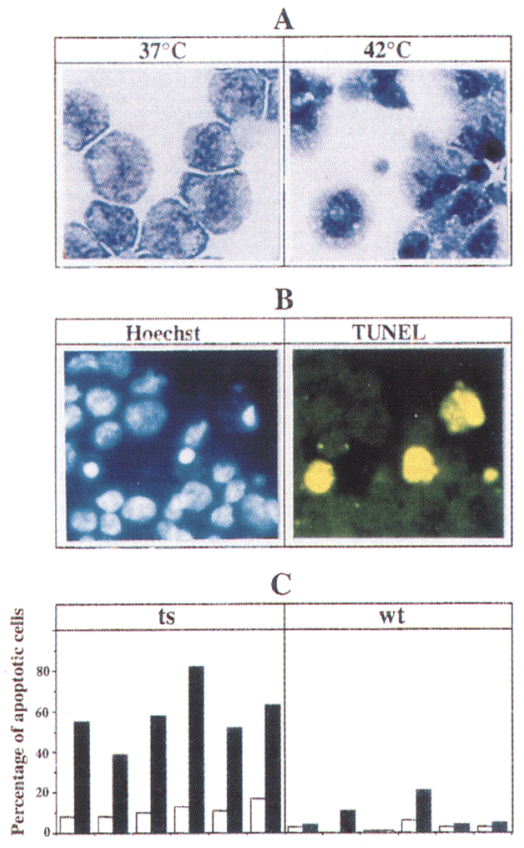

Individual myeloblast clones

Figure 1. Induction of apoptotis in ts21 transformed myeloblasts shifted to $42^{\circ} \mathrm{C}$. (A) Giemsa stained cytospins of ts 21 (Myb ${ }^{\text {ts }}$-Ets) transformed myeloblasts grown at $37^{\circ} \mathrm{C}$ or shifted to $42^{\circ} \mathrm{C}$ for $60 \mathrm{hr}$. Cells with characteristics of programmed cell death can be seen in the shifted population. (B) Immunofluorescence staining of apoptotic cells in the $t s 21$ transformed cell sample shifted to $42^{\circ} \mathrm{C}$. The same field is viewed with different filters to show staining of all nuclei (Hoechst) and those that are apoptotic (TUNEL). Note that the apoptotic cells can also be recognized by Hoechst staining because of their condensed chromatin. (C) Quantification of the induction of apoptosis in individual myeloblast clones. Six independent clones transformed by either wild-type $\mathrm{E} 26$ or $t s 21$ were grown at $37^{\circ} \mathrm{C}$ (open bars) or $42^{\circ} \mathrm{C}$ (solid bars) for $60 \mathrm{hr}$ and the percentage of apoptotic cells determined by TUNEL staining. The average number of positive cells at $37^{\circ} \mathrm{C}$ compared with $42^{\circ} \mathrm{C}$ was $11.2 \%$ and $58.0 \%$ for $t s 21$ cells and $2.5 \%$ and $7.7 \%$ for wild-type E26 cells. characteristic of programmed cell death. This was confirmed by labeling the cells by the TUNEL technique, which visualizes DNA fragments generated by endonucleolytic cleavage (Fig. 1B). To quantify this effect, six randomly chosen clones transformed at $37^{\circ} \mathrm{C}$ by $t s 21$ E26 or wild-type E26 were split and either kept at $37^{\circ} \mathrm{C}$ or shifted to $42^{\circ} \mathrm{C}$ for $60 \mathrm{hr}$. As shown in Figure 1C, there was a dramatic increase in the number of apoptotic cells in all ts21-transformed clones at $42^{\circ} \mathrm{C}$ but only a slight increase in the wild-type E26 myeloblasts under the same conditions. In addition, ts 21 -transformed clones already exhibited an elevated level of apoptotic cells at $37^{\circ} \mathrm{C}$ relative to the wild-type E26 clones, possibly reflecting the fact that the DNA binding capacity of the mutant Myb DNA binding domain is partially impaired at the permissive temperature (Frampton et al. 1995).

These results show that inactivation of the Myb-Ets oncoprotein in transformed myeloblasts induces apoptosis in a large fraction of the cells.

\section{The antiapoptotic effect of ts21 E26 is mediated by $\checkmark-M y b$}

The fact that the lesion in ts 21 E26 is located in the DNA binding domain of Myb, completely abolishing the specific DNA binding capacity of v-Myb at $42^{\circ} \mathrm{C}$ (Frampton et al. 1995), suggests that the observed antiapoptotic effect of Myb-Ets is a result of the Myb portion of the oncoprotein. However, it is possible that the mutation acts indirectly by affecting the v-Ets portion of the molecule, which, like v-Myb, consists of DNA binding and transactivation domains. Earlier work with MEPs transformed by a mutant of E26 with a lesion in the DNA binding domain of Ets (ts 1.1 E26) that renders its DNAbinding capacity temperature-sensitive showed that the cells are induced to differentiate predominantly along the erythroid lineage when shifted to $42^{\circ} \mathrm{C}$; however, $\mathrm{v}$-Ets inactivation had no effect on the differentiation of ts1.1-transformed myeloid cells. (Golay et al. 1988; Kraut et al. 1994). We, therefore, tested whether programmed cell death would be induced in ts1.1-transformed myeloid cells at the nonpermissive temperature. As shown in Figure 2A, of three ts1.1-transformed myeloid cell clones tested, none exhibited a significant increase in apoptosis at $42^{\circ} \mathrm{C}$, even as late as $80 \mathrm{hr}$ after shift. In contrast and as expected, a sizable proportion of two ts21-transformed myeloblast clones grown in parallel and shifted under identical conditions died by apoptosis.

These results support the idea that the antiapoptotic effect of Myb-Ets is confined to the $\mathrm{v}$-Myb portion of the fusion protein. However, they do not rule out the possibility that apoptosis is prevented by an interaction between the two domains within the fusion protein. To examine this possibility we assessed whether myeloid cells transformed by a separately expressed temperaturesensitive v-Myb would undergo apoptosis at $42^{\circ} \mathrm{C}$. Because cells transformed by v-Myb have a limited growth potential, we used myeloid cells transformed by a variant of $t s 21$ E26 in which Myb and Ets are expressed sep- 

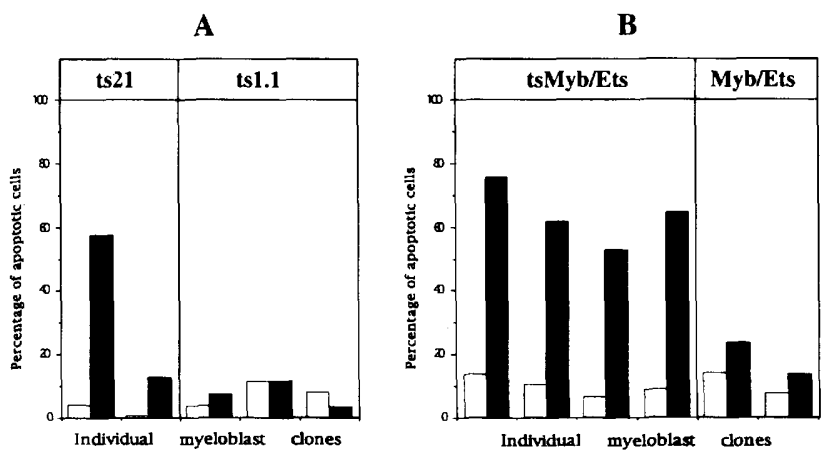

Figure 2. Requirement of functional v-Myb for protection from apoptosis. $(A)$ Comparison of the number of apoptotic cells in two clones transformed by $t s 21\left(\mathrm{Myb}^{\mathrm{ts}}-\mathrm{Ets}\right)$ and in three myeloblast clones transformed by $t s 1.1$ (Myb-Ets ${ }^{\text {ts }}$ ) grown at $37^{\circ} \mathrm{C}$ (open bars) or $42^{\circ} \mathrm{C}$ (solid bars) for $72 \mathrm{hr}$. (B) Comparison of the number of apoptotic cells in four myeloblast clones transformed by $t s \mathrm{Myb} / \mathrm{Ets}$ and in two clones transformed by $\mathrm{Myb} /$ Ets grown at $37^{\circ} \mathrm{C}$ (open bars) or $42^{\circ} \mathrm{C}$ (solid bars) for $72 \mathrm{hr}$.

arately (ts Myb/Ets) (Metz and Graf 1991b). As shown in Figure 2B, of four clones transformed by $t s \mathrm{Myb} / \mathrm{Ets}$, all showed a dramatic increase in apoptosis at $42^{\circ} \mathrm{C}$ wheres two clones transformed by wild-type Myb/Ets only showed a marginal increase. We conclude that the myeloid survival-inducing function of the Myb-Ets oncoprotein is mediated by its $\mathrm{v}-\mathrm{Myb}$ moiety.

\section{The antiapoptotic effect of $V-M y b$ is cell type-specific}

We have shown previously that $t s 21$ E26-transformed MEPs shifted to the nonpermissive temperature differentiate into mature thrombocytes within 2-3 days (Frampton et al. 1995). To test whether this also leads to an increased rate of apoptosis we shifted eight clones individually transformed by either $t s 21$ or wild-type E26 to $42^{\circ} \mathrm{C}$ for $60 \mathrm{hr}$, or kept them at $37^{\circ} \mathrm{C}$. Surprisingly, none of the clones showed an increased rate of apoptosis at the nonpermissive temperature. On the contrary, the majority of the $t s 21$ clones actually exhibited a slightly decreased rate of apoptosis at $42^{\circ} \mathrm{C}$. This effect was mutant-specific as it was not seen with wild-type E26-transformed MEPs (Fig. 3).

\section{Inactivation of $\mathrm{V}-\mathrm{Myb}$ in transformed myeloblasts down-regulates bcl-2 expression}

To examine whether $b c l-2$ expression is affected by $\mathrm{v}$-Myb inactivation, a Northern blot analysis was performed with RNAs from $t s 21$ and wild-type E26 myeloblasts grown at $37^{\circ} \mathrm{C}$ or shifted to $42^{\circ} \mathrm{C}$. As shown in Figure 4A, $b c 1-2$ RNA was almost completely down-regulated after a $24-\mathrm{hr}$ shift to $42^{\circ} \mathrm{C}$ in the $t s 21$ but not in the wild-type cells, and became reexpressed within only $2 \mathrm{hr}$ when the cells were backshifted to $37^{\circ} \mathrm{C}$. The loss of bcl-2 RNA and its rapid reappearance after backshift was paralleled by the pattern of expression of mim-1, a previously identified direct target gene of $\mathrm{v}-\mathrm{Myb}$. In the

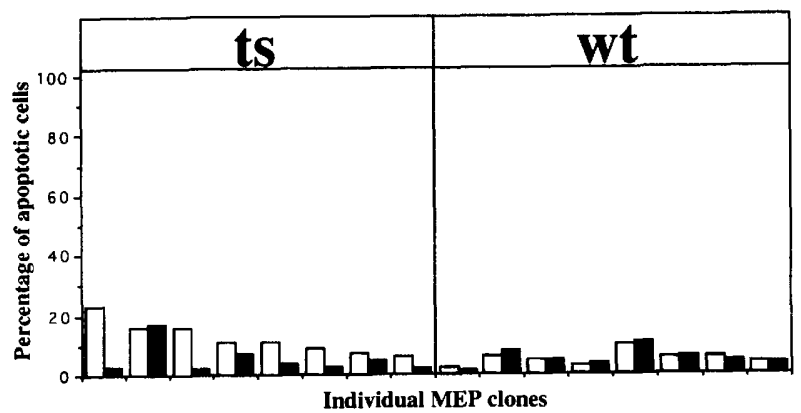

Figure 3. Lack of induction of apoptosis in ts 21 transformed MEPs shifted to $42^{\circ} \mathrm{C}$. The figure shows a comparison of the number of apoptotic cells in eight individual MEP clones transformed by $t s 21$ or wild-type $\mathrm{E} 26$ and grown at $37^{\circ} \mathrm{C}$ (open bars) or $42^{\circ} \mathrm{C}$ (solid bars) for $60 \mathrm{hr}$.

same experiment RNA of c-fms (a marker of mature myeloid cells that encodes the CSF-1 receptor) was up-regulated at $42^{\circ} \mathrm{C}$ and remained unchanged for $2 \mathrm{hr}$ after backshift. In contrast to the results obtained with myeloid cells, no significant change in the expression of bcl-2 RNA could be observed in ts21-transformed MEPs after shift to $42^{\circ} \mathrm{C}$ (Fig. $4 \mathrm{~B}$ ).

The observed down-regulation of $b c l-2$ RNA in $t s 21$ transformed myeloblasts within 1 day at $42^{\circ} \mathrm{C}$, together with the finding that increased apoptosis became apparent only after 2-3 days, raised the question of whether both processes are related. We therefore examined by Western blotting the change in $\mathrm{Bcl}-2$ protein levels when ts21-transformed myeloblasts grown at $37^{\circ} \mathrm{C}$ were shifted to $42^{\circ} \mathrm{C}$ for $24 \mathrm{hr}$. In addition, we probed the blot for MAP kinase as a control for protein levels and for cdc2 as an indication of the cell cycling status. As shown in Figure 4C, Bcl-2 expression was reduced significantly whereas no change was seen for MAP kinase. In contrast the cdc2 protein was no longer detectable, reflecting the fact that the cells had exited the cell cycle. This result confirms the known relatively long half-life of Bcl-2 (Kitada et al. 1993) compared with cdc2 kinase.

We also tested whether the reexpression of $b c l-2$ mRNA upon backshift to $37^{\circ} \mathrm{C}$ occurred in the presence of the protein synthesis inhibitor cycloheximide. Backshifting of $t s 21$ myeloblasts that had been grown at $42^{\circ} \mathrm{C}$ for $40 \mathrm{hr}$ was performed for $2 \mathrm{hr}$ in the presence or absence of $5 \mu \mathrm{g} / \mathrm{ml}$ cycloheximide. As can be seen in Figure $4 \mathrm{D}$, the extent of reactivation was little affected by this treatment.

In summary, $b c l-2$ mRNA is down-regulated in myeloid cells when $\mathrm{v}$-Myb is inactivated and becomes rapidly reexpressed upon $\mathrm{v}-\mathrm{Myb}$ reactivation even when de novo protein synthesis is inhibited. In addition, the relatively late onset of apoptosis compared with the reduction in RNA expression correlates with the presence of residual Bcl-2 protein and probably reflects the protein's high stability.

Forced expression of bcl-2 in ts 21 myeloblasts shifted to $42^{\circ} \mathrm{C}$ prevents apoptosis but not growth arrest

To test whether apoptosis induced by $\mathrm{v}-\mathrm{Myb}$ inactiva- 


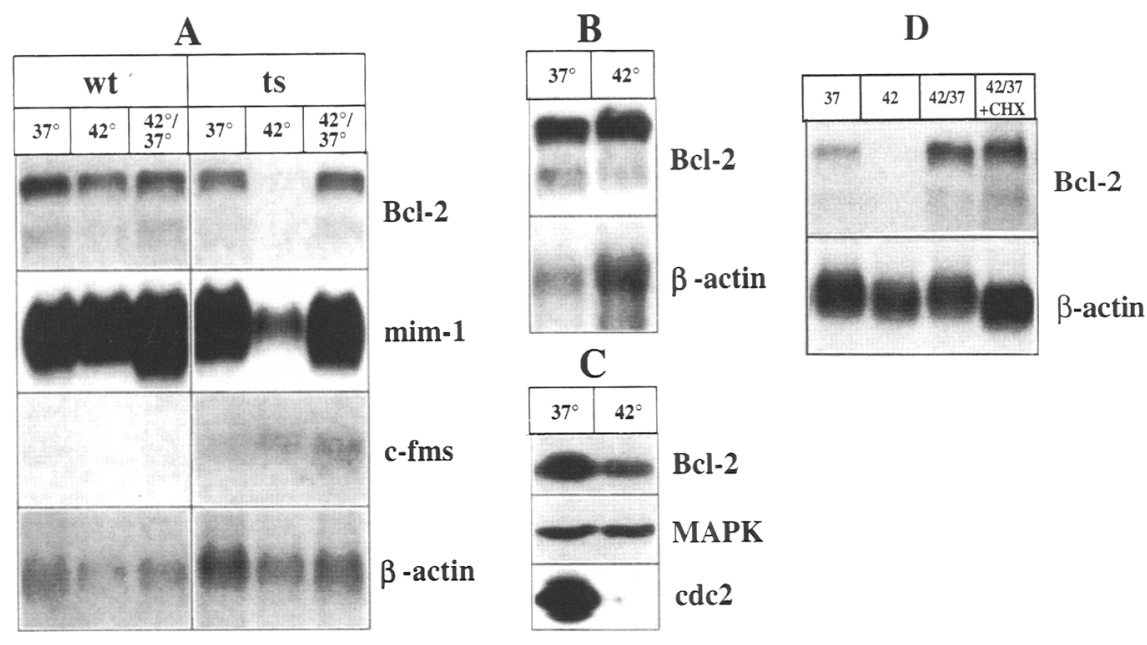

Figure 4. Down-regulation of $b c l-2$ RNA expression in $t s 21$ transformed myeloblasts shifted to $42^{\circ} \mathrm{C}$. (A) Northern blot of RNAs from wild-type E26 and $t s 21$ transformed myeloblasts grown at $37^{\circ} \mathrm{C}, 42^{\circ} \mathrm{C}$ for $24 \mathrm{hr}$, or $42^{\circ} \mathrm{C}$ for $24 \mathrm{hr}$ and then shifted back to $37^{\circ} \mathrm{C}$ for $2 \mathrm{hr}$. The blot was probed sequentially with $b c l-2, \mathrm{mim}-1$, c-fms, and $\beta$-actin cDNA probes. $(B)$ Northern blot of RNAs from ts 21 transformed MEPs grown as described in $A$ and probed with $b c l-2$ and $\beta$-actin. Quantification of the signals by scanning of the autoradiograms allowed an approximate comparison of the $b c l-2 / \beta$-actin RNA ratios. Setting the ratio to unity for the $37^{\circ} \mathrm{C}$ lanes, then the $t s 21$ myeloblasts at $42^{\circ} \mathrm{C}$ exhibit a ratio of $<0.15$ as compared with 0.8 for $t s 21$ MEPs under the same conditions. (C) Western blot of total cell extracts derived from $10^{6} \mathrm{ts} 21$ myeloblasts grown at $37^{\circ} \mathrm{C}$ or at $42^{\circ} \mathrm{C}$ for $24 \mathrm{hr}$. The lysates were run on a $10 \%$ polyacrylamide gel, blotted, and probed sequentially with antibodies directed against Bcl-2, MAP kinase, and cdc2, by use of the ECL technique. (D) Northern blot of RNAs from $t s 21$ transformed myeloblasts probed for $b c l-2$ and $\beta$-actin. The RNAs were prepared from cells grown at $37^{\circ} \mathrm{C}, 42^{\circ} \mathrm{C}$ for $40 \mathrm{hr}, 42^{\circ} \mathrm{C}$ for $40 \mathrm{hr}$, and then backshifted to $37^{\circ} \mathrm{C} \mathrm{for} 2 \mathrm{hr}$, or $42^{\circ} \mathrm{C} \mathrm{for} 40 \mathrm{hr}$, and backshifted to $37^{\circ} \mathrm{C}$ in the presence of $5 \mu \mathrm{g} / \mathrm{ml}$ cycloheximide (CHX).

tion can be prevented by forced expression of $b c l-2$, we designed a retrovirus that coexpresses the Myb-Ets fusion protein and Bcl-2 from a single bicistronic mRNA (Fig. 5A). We found that ectopic Bcl-2 reduced the degree of apoptosis induced by $\mathrm{v}$-Myb inactivation in all seven clones tested, to a level comparable to clones transformed by wild-type E26 (Fig. 5B). To determine whether the cells still became quiescent, they were labeled with bromodeoxyuridine (BrdU) and their DNA content was analyzed by flow cytometry. As shown in Figure 6, 55\% and $63 \%$, respectively, of the $t s 21$ and $t s 21 / b c l-2$ trans-

A

\begin{tabular}{|l|l|l|}
\hline & Stop NcoI(ATG) \\
\hline LTR & Xba I(St op ) \\
\hline
\end{tabular}

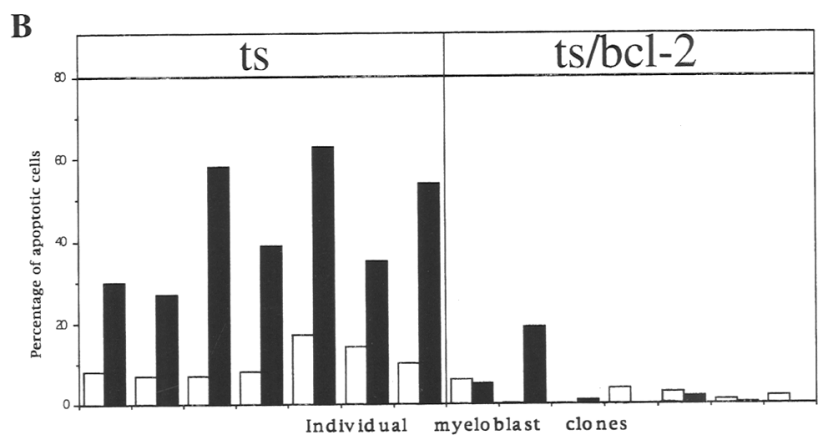

Figure 5. Effect of forced Bcl-2 expression on cell survival. $(A)$ Schematic representation of the $\mathrm{Myb}^{\mathrm{ts}}-\mathrm{Ets} / \mathrm{Bcl}-2$ retrovirus. The internal ribosome entry site (IRES), the viral long terminal repeats (LTR), and the second initiating ATG codon are indicated. $(B)$ Comparison of the proportion of apoptotic cells in seven myeloblast clones transformed by $t s 21$ or $t s 21 / b c l-2$ grown at $37^{\circ} \mathrm{C}$ (open bars) or $42^{\circ} \mathrm{C}$ (solid bars) for $60 \mathrm{hr}$. formed myeloblasts grown at $37^{\circ} \mathrm{C}$ incorporated $\mathrm{BrdU}$ and $>40 \%$ of these cells had progressed to $\mathrm{G}_{2} / \mathrm{M}$. In contrast, only $16 \%$ and $17.5 \%$ respectively of the cells were labeled in the corresponding populations after shift to $42^{\circ} \mathrm{C}$ and of these $<20 \%$ had entered $\mathrm{G}_{2} / \mathrm{M}$. The BrdU negative population with low DNA content seen in the ts 21 cells grown at $42^{\circ} \mathrm{C}$ probably consists of fragmented

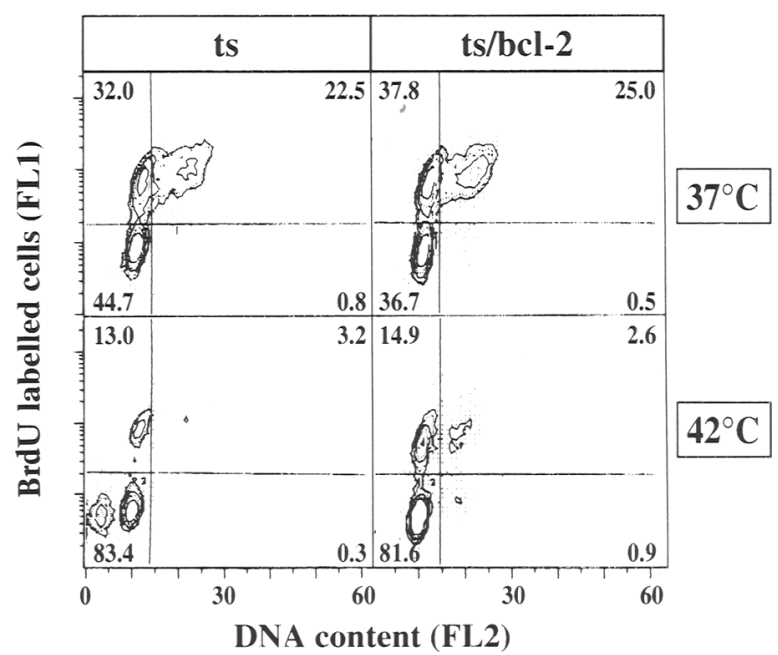

Figure 6. Effect of forced Bcl-2 expression on the cell cycle. Analysis of nuclear DNA content and the proportion of cells entering $\mathrm{S}$ phase. The diagram shows a flow cytometric analysis of $t s 21$ or $t s 21 / b c l-2$ transformed myeloblast clones grown at $37^{\circ} \mathrm{C}$ or at $42^{\circ} \mathrm{C}$ for 2 days. Cells that incorporated BrdU (included in the last $12 \mathrm{hr}$ of the incubation period) were detected by immunofluorescence (FLl) and total DNA content was monitored by propidium iodide staining (FL2). 
nuclei from apoptotic cells because no such population is seen in the $t s 21 / b c l-2$ sample.

These findings show that the induction of apoptosis in $t s 21$ myeloblasts at $42^{\circ} \mathrm{C}$ can be prevented by forced $b c l-2$ expression, without affecting the cell's withdrawal from the cell cycle.

\section{ts21/bcl-2 myeloblasts shifted to $42^{\circ} \mathrm{C}$ differentiate} into both macrophage-and granulocyte-like cells

Next we tested whether ectopic $b c l-2$ expression has an effect on the temperature-induced differentiation of ts $21 / b c l-2$ transformed myeloblasts. For this purpose, we analyzed the cell morphology of 11 clones transformed by either $t s 21$ or $t s 21 / \mathrm{bcl}-2$, kept at $37^{\circ} \mathrm{C}$ or shifted to $42^{\circ} \mathrm{C}$ for 3 days. In several of the shifted clones ectopic expression of $b c l-2$ led to the formation of granules characteristic of immature avian neutrophil granulocytes (Lucas and Jamroz 1961; Golay et al. 1988). In the same clones similar cells were already detectable at $37^{\circ} \mathrm{C}$, although at lower proportions than at $42^{\circ} \mathrm{C}$. This is illustrated for clone $\mathrm{C} 10$ in the micrograph of Figure 7A and quantified for all clones in Figure $7 \mathrm{~B}$. Other clones shifted to $42^{\circ} \mathrm{C}$ resembled immature macrophages, although their differentiation was less dramatic than that of $t s 21$ clones shifted to $42^{\circ} \mathrm{C}$. This is shown for clone D4 in Figure 7A. When a pool of $t s 21 / b c l-2$ transformed myeloblasts shifted to $42^{\circ} \mathrm{C}$ was examined for the expression of the Myb target gene mim-l they showed a clear decrease of expression with time although this downregulation was less severe than in $t s 21$ myeloblasts in the absence of ectopically expressed Bcl-2 (Fig. 7C).

These results show that forced $b c l-2$ expression in $t s 21$ myeloblasts shifted to $42^{\circ} \mathrm{C}$ allows the detection of granulocyte-like cells in addition to the macrophage-like cells that are typically seen when $b c l-2$ is not overexpressed. In addition, it appears that $b c l-2$ partially impairs macrophage differentiation.

\section{Withdrawal of cMGF from Myb-Ets transformed myeloblasts causes growth arrest but not apoptosis}

The proliferation of myelomonocytic cells transformed by the E26 virus is dependent on the presence of chicken myelomonocytic growth factor (cMGF) (Beug et al. 1982; Leutz et al. 1984). To determine whether factor withdrawal has an impact on cell death, $t s 21$ myeloblasts were thoroughly washed and reseeded at $37^{\circ} \mathrm{C}$ in the presence or absence of cMGF. As a control, the cells were also shifted to $42^{\circ} \mathrm{C}$ in the presence of cMGF. Sixty hours later the number of apoptotic cells was determined and the growth rate of the population assessed by thymidine incorporation. As shown in Figure 8A, ts 21 myeloblasts grown at $37^{\circ} \mathrm{C}$ exhibited no appreciable increase in cell death upon removal of the growth factor. Nevertheless, growth factor withdrawal resulted in a 3- to 4-fold decrease in thymidine incorporation (Fig. 8B). As expected, ts 21 myeloblasts shifted to $42^{\circ} \mathrm{C}$ showed a significant increase in apoptosis in addition to a decreased level of thymidine incorporation.
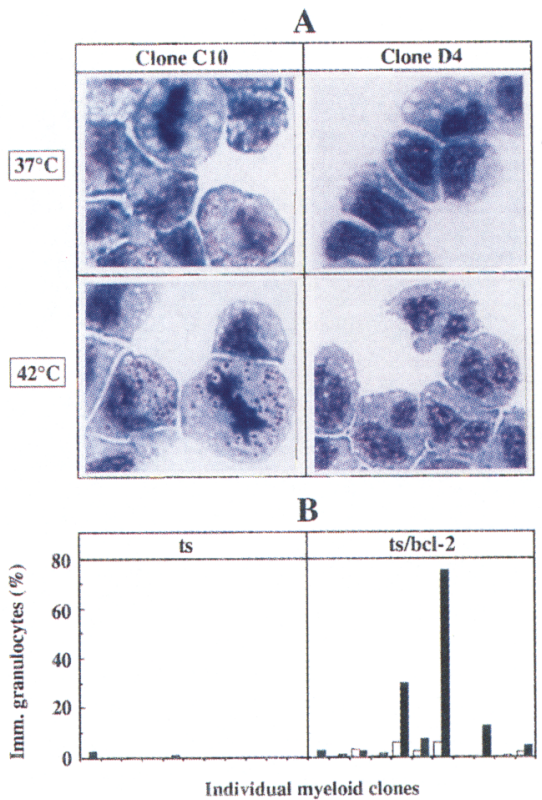

C

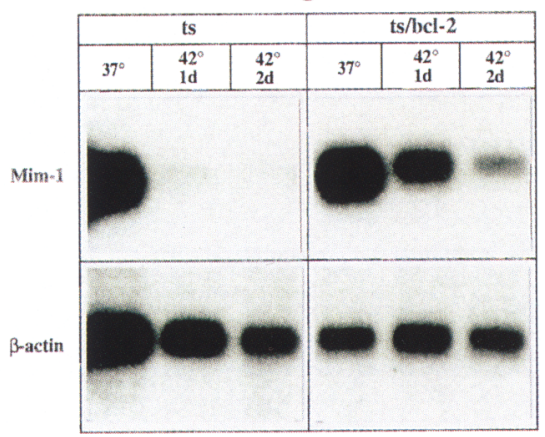

Figure 7. Effect of forced Bcl-2 expression on differentiation. (A) Micrographs of cells prepared by cytocentrifugation and $\mathrm{Gi}-$ emsa staining of $t s 21 / \mathrm{bcl}-2$ clones grown at $37^{\circ} \mathrm{C}$ and $42^{\circ} \mathrm{C}$. Clones $\mathrm{C} 10$ and $\mathrm{D} 4$ represent examples that mature predominantly into more granulocytic or monocytic phenotypes, respectively. $(B)$ Quantification of granulocytic differentiation of individual $t s 21$ or $t s 21 / \mathrm{bcl}-2$ transformed myeloblast clones grown for 4 days at $37^{\circ} \mathrm{C}$ (open bars) or at $42^{\circ} \mathrm{C}$ (solid bars). (C) Northern blot of $5 \mu \mathrm{g}$ total RNA derived from ts 21 or $t s 21 / b c l-2$ transformed myeloblast clones grown at $37^{\circ} \mathrm{C}$ or at $42^{\circ} \mathrm{C}$ for $\mathrm{l}$ or 2 days. The blot was hybridized sequentially with probes for mim- 1 and $\beta$-actin.

These results show that growth factor depletion of Myb-Ets transformed myeloid cells leads to their withdrawal from the cell cycle without inducing apoptosis.

\section{Myb binds to specific sites on the bcl-2 P2 promoter}

The observed rescue by Bcl- 2 of $t s 21$ myeloblasts shifted to $42^{\circ} \mathrm{C}$ and the rapid reexpression of $b c l-2$ RNA during backshift raised the possibility that the $b c l-2$ gene is regulated directly by Myb. The human $b c l-2$ promoter has been shown to have two major sites of transcription initiation (Seto et al. 1988); an upstream site (P1), which has 
A

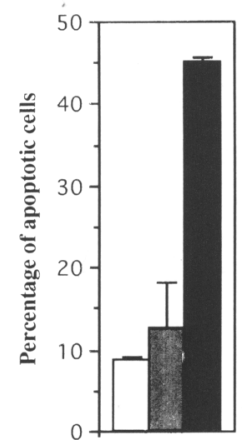

B

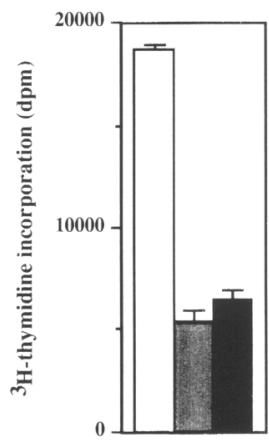

Figure 8. Effect of growth factor withdrawal on transformed myeloblasts. Two ts 21 transformed myeloblast clones were grown for $60 \mathrm{hr}$ at $37^{\circ} \mathrm{C}$ or at $42^{\circ} \mathrm{C}$ in the presence of cMGF (open and solid bars, respectively) or at $37^{\circ} \mathrm{C}$ in the absence of cMGF (gray bars). Aliquots of the cells were then stained with Hoechst to determine the proportion of apoptotic cells $(A)$ or labeled for $2 \mathrm{hr}$ with ${ }^{3} \mathrm{H}$-thymidine $(B)$ to determine their growth potential.

features of a housekeeping-type promoter and which drives expression of RNA starting at exon 1 , and a second site (P2), which is located within exon 2. Inspection of the sequences of the P2 promoters of the human (Seto et al. 1988), mouse (Negrini et al. 1987), and chicken bcl-2 genes (Eguchi et al. 1992; Fig. 9A) revealed a number of perfect matches to the core Myb consensus recognition element (Weston 1992) whereas no such matches were found in the Pl region. To identify sites which are capable of binding to Myb in vitro we performed a DNaseI footprint analysis of a fragment encompassing the P2 promoter with bacterially expressed Myb. As shown in Figure 9B, of the four consensus Myb binding sites (MREs) present in the sequence analyzed (Fig. 9A), three were found to be protected by Myb.

\section{Myb transactivates a reporter driven by the bcl-2 P2 promoter, requiring intact $M y b$ binding sites}

To determine whether Myb transactivates the $b c l-2$ promoter we constructed a luciferase reporter driven by the chicken bcl-2 P2 region and tested its activity in transient transfection assays. For comparison, we tested a reporter driven by the MRE from the mim-l gene. Cotransfection of a vector expressing the Myb-Ets fusion protein with the $b c l-2$ P2 promoter led to a $\sim 12$-fold activation of the promoter, compared with a $\sim 27$-fold effect on the mim-1 promoter (Fig. 10A). In addition, Myb-Ets was significantly more active on the wild-type $b c 1-2 \mathrm{P} 2$ promoter than on a mutated version in which each of the four MREs were altered so as to impair binding by Myb (Fig. 10B). As the E26 v-Myb lacking the Ets sequences was found to stimulate transcription from the $b c 1-2$ P2 promoter only by a factor of $1.5-2$, we determined whether the activity of $\mathrm{v}$-Myb could be enhanced by fusing the oncoprotein with the strong VP16 activation domain. This had been found previously to increase

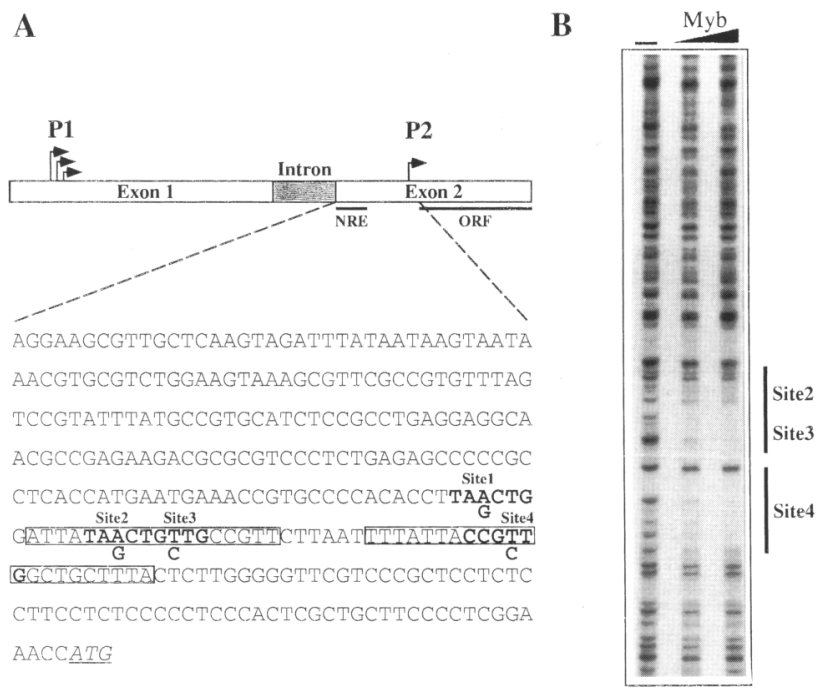

Figure 9. The chicken $b c l-2$ promoter and Myb binding sites. (A) Schematic representation of the chicken bcl-2 promoter showing the first two exons. (NRE) Negative regulatory element; (ORF) open reading frame. The blowup shows the sequence of exon 2 until the translation initiation codon. Consensus Myb recognition elements (Sites 1-4) are indicated by bold letters; sequences that are protected by Myb (see below) are boxed. The location of the mutations introduced within the four potential Myb binding sites is indicated (A to $\mathrm{G}$ or $\mathrm{T}$ to $\mathrm{C}$ ). (B) DNAse nuclease protection analysis of the chicken $b c l-2$ P2 promoter with bacterially expressed Myb. DNA prepared in the absence of Myb (lane 1); with $0.2 \mu \mathrm{g}$ of Myb (lane 2); with $2 \mu \mathrm{g}$ of Myb (lane 3). The two regions protected from digestion by DNAse are indicated and correspond to the boxed sequences in $A$.

its activity on the mim-1 promoter (Frampton et al. 1993). As shown in Figure 10C, v-Myb-VP16 gave a 4- to 5 -fold activation of the wild-type $b c l-2 \mathrm{P} 2$ promoter and only a marginal activation of its mutated version.

These observations indicate that the $b c l-2$ P2 promoter can be transactivated both by Myb-Ets and by $\mathrm{v}-\mathrm{Myb}-\mathrm{VP} 16$ and that this requires intact Myb binding sites within the promoter.

\section{Discussion}

Using a temperature-sensitive mutant of the E26 leukemia virus encoding Myb-Ets we have shown here that a functional form of $\mathrm{v}-\mathrm{Myb}$ prevents primary chicken myeloblasts from undergoing apoptosis. This is paralleled by the ability of the oncoprotein to maintain high levels of $b c l-2$ expression through what appears to be a direct effect on the promoter of the gene. The antiapoptotic properties of Myb-Ets can explain, at least in part, its capacity to transform myelomonocytic cells and makes it the first nuclear oncoprotein for which a transformation relevant target gene has been identified. Using a similar ts mutant approach, $\mathrm{v}$-Rel has been shown to rescue $\mathrm{T}$ cells from apoptosis, although a direct target responsible for this effect has not been described (White 
A

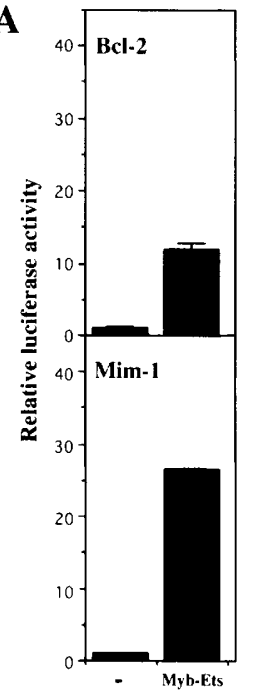

B

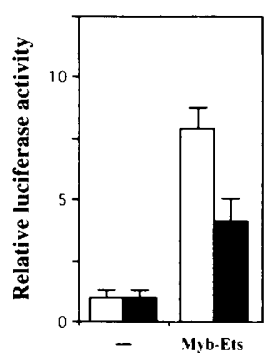

C

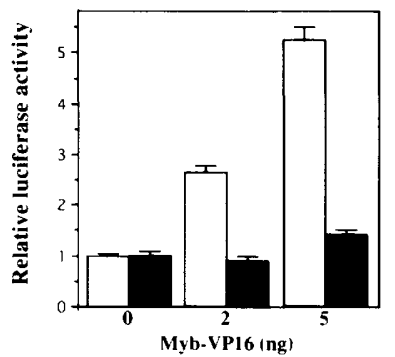

Figure 10. Transactivation of the $b c l-2 \mathrm{P} 2$ promoter. (A) Transactivation by Myb-Ets. QT6 fibroblasts were cotransfected with either the $b c l-2 / \mathrm{P} 2$ or the mim-l luciferase reporter together with either $10 \mathrm{ng}$ of the Myb-Ets expressing plasmid or the corresponding vector DNA $(-),(B, C)$ Requirement for intact Myb binding sites within the $b c l-2 \mathrm{P} 2$ promoter for transactivation by Myb-Ets and Myb-VP16. Transfections were performed with either the $b c l-2-\mathrm{P} 2$ reporter (Bcl-2) (open bars) or the mutated reporter construct (Bcl-2 mut) (solid bars) together with $(B)$ the Myb-Ets expressing plasmid $(10 \mathrm{ng})$ or with $(C)$ the construct expressing v-Myb-VPl6 (2 ng or $5 \mathrm{ng}$ ).

et al. 1994|. Likewise, the mechanism by which Myc and AP-1 accelerate apoptosis in fibroblasts and in neuronal cells (Evan et al. 1992; Ham et al. 1995) has yet to be elucidated. However, it has been reported recently that apoptosis induced by the tumor suppressor protein $\mathrm{p} 53$ is mediated by its direct activation of the death promoting gene bax (Miyashita and Reed 1995).

\section{Is the bcl-2 gene a direct target of $\mathrm{v}-\mathrm{Myb}$ ?}

A number of observations suggest that v-Myb directly controls $b c l-2$ expression through interaction with the P2 promoter of the gene. P2 is located upstream of the translation initiation site in exon 2; this region also contains a negative regulatory element implicated in stagespecific expression of $b c l-2$ in human B cells (Young and Korsmeyer 1993) and confers sensitivity to p53 in human lung and murine Ml myeloid leukemic cells (Miyashita et al. 1994a,b). In the equivalent region of the chicken $b c l-2$ gene we now have identified three MREs whose integrity is required for the promoter's full responsiveness to Myb-Ets and v-Myb. In addition, we found that ts 21 myeloblasts shifted back from $42^{\circ} \mathrm{C}$ to $37^{\circ} \mathrm{C}$ reaccumulate $b c l-2$ RNA within only $2 \mathrm{hr}$, with kinetics similar to those seen for the Myb-regulated gene mim-1 (Ness et al. 1989). Finally, and again as for the mim-1 gene, we observed reexpression of $b c l-2$ RNA in the presence of cycloheximide, indicating that de novo protein

synthesis is not required upon reactivation of $\mathrm{v}-\mathrm{Myb}$. These results support the idea that $\mathrm{v}$-Myb regulates the $b c l-2$ promoter by directly binding to it.

The finding that $\mathrm{Myb}-\mathrm{Ets}$ is more active in regulating $b c l-2$ P2 than $\mathrm{v}-\mathrm{Myb}$ raises the possibility that the Ets portion of the fusion protein also participates in $b c l-2$ activation, such as by binding to other sites of the promoter. Indeed, several GGAA/T Ets core binding sites can be identified in the $\mathrm{P} 2$ promoter. However, in myeloid cells transformed by a ts mutant of E26 with a lesion in Ets, we observed no effect on apoptosis upon shifting to the nonpermissive temperature. In addition, since Myb-Ets has been found to be more active than $\mathrm{v}-\mathrm{Myb}$ on promoters not known to contain Ets responsive elements, such as that of the mim-1 gene (Frampton et al. 1993), the Ets domain of the oncoprotein might not bind to DNA but instead serve to recruit other factors to the transcription activation complex. This would be consistent with the recent identification of nuclear proteins that specifically interact with c-Ets-1 (Sieweke et al. 1996).

\section{$M y b$, cell transformation, and differentiation}

$\mathrm{v}-\mathrm{Myb}$ is known to arrest the differentiation of myeloid cells (Beug et al. 1984, 1987) at a stage where their normal counterparts express $b c l-2$ (see below). It is, therefore, difficult to assess the relationship between the differentiation-blocking and the survival-inducing capacity of the oncoprotein. For the reasons outlined above, it is unlikely that Myb targets that mediate the differentiation block active $b c l-2$ indirectly. However, it is still possible that Myb concomitantly regulates both $b c l-2$ and unknown target genes involved in blocking differentiation, or that it only activates $b c l-2$, which in turn mediates the differentiation block. Our data suggest that a combination of the latter possibilities might be correct because forced expression of $b c l-2$ in $t s 21$ cells shifted to $42^{\circ} \mathrm{C}$ not only prevented apoptosis but also slightly impaired differentiation into macrophages. This phenomenon deserves further study. The finding that cMGF withdrawal causes growth arrest without inducing apoptosis is consistent with a constitutive up-regulation of $b c l-2$ in Myb-Ets-transformed myeloblasts. In contrast, in spontaneously transformed myeloid cell lines such as FDCP-1 or FDCP-2, factor deprivation induces apoptosis (Fairbairn et al. 1993). In addition, it has been shown recently that forced expression of Myb-Ets in FDCP-2 cells (kept in the presence of erythropoietin) prevents them from apoptotic death following withdrawal of IL-3 (Athanasiou et al. 1996).

Although activation and maintenance of $b c l-2$ expression appears to be required for the myeloid cell transforming capacity of $\mathrm{v}-\mathrm{Myb}$, it is not likely to be sufficient. Thus, the oncoprotein not only blocks differentiation but also facilitates differentiation and induces cell proliferation (for review, see Graf 1992). Several myeloid differentiation specific genes have been described that are directly activated or repressed by $\mathrm{v} / \mathrm{c}-\mathrm{Myb}$ in conjunction with other transcription factors, such as mim-1 
(Ness et al. 1989), the CD13 aminopeptidase gene (Shapiro 1995), and c-fms (Reddy et al. 1994). However, because none of these targets seem to be involved in controlling growth or in blocking differentiation, it is doubtful that they play a role in cell transformation by v-Myb.

The observed capacity of $\mathrm{v}-\mathrm{Myb}$ to regulate $b c l-2 \mathrm{ex}$ pression cannot be a general explanation for the transforming capacity of the oncoprotein because ts21-transformed MEPs do not undergo apoptosis and retain high levels of $b c l-2$ expression. This indicates that $b c l-2$ is controlled independently from v-Myb in MEPs and suggests that the mechanism by which the oncogene transforms cells differs according to the cell type involved. In support for this notion is the fact that v-Myb does not transform fibroblasts (or does so only weakly) (Graf 1973; Beug et al. 1984). The diversity of transformation mechanisms by $\mathrm{v}$-Myb probably reflects the requirement to act in concert with other tissue-restricted trancription factors. For example, Myb-Ets regulates the expression of the mim-1 gene in transformed myeloblasts but not in MEP cells (Ness et al. 1989); this is accounted for by its cooperation with C/EBP $\beta$, a protein whose expression in hematopoietic tissues mirrors that of Mim-1 (Burk et al. 1993; Ness et al. 1993).

\section{$M y b, B c l-2$, and leukemogenesis}

A question raised by our findings is whether the antiapoptotic effect of $\mathrm{v}-\mathrm{Myb}$ is relevant to the leukemogenic potential of the oncogene. As the predominant type of leukemic cells induced by the E26 virus corresponds to immature erythroid/MEP-type cells, with variable contributions of myeloblasts (Radke et al. 1982; Graf et al. 1992), the answer is not simple. v-Myb of E26, either alone or in combination with a separately expressed v-Ets, is not leukemogenic or only weakly so (Metz and Graf 1991b/ and may reflect the factor dependence of both $\mathrm{v}-\mathrm{Myb}$ and Myb/Ets transformed myeloblasts (Leutz et al. 1984). Indeed, viruses containing E26 v-Myb (in the absence of Ets) together with either an autocrine growth-inducing oncogene, such as verbB or the cMGF gene, cause acute myeloblastic leukemias (Metz et al. 1991). In addition, the highly mutated v-Myb protein of AMV virus possibly causes monoblastic leukemia because the transformed cells also appear to produce an autocrine growth factor (for review, see Graf 1992). This might make it difficult to determine whether AMV, like E26, protects primary myeloid cells from apoptosis.

Our observations raise the possibility that alterations in the $c-m y b$ gene, resulting in $b c l-2$ up-regulation and prevention of apoptosis, may contribute to the generation of human myeloid leukemias. Although rearrangements, amplifications or overexpressions of $c-m y b$ have been reported for only a relatively small number of human lymphoid and myeloid malignancies (for review, see Lüscher and Eisenman 1990; Shen-Ong 1990|, more subtle alterations such as point mutations might have been missed. It is striking that most human acute and chronic myeloid leukemias in blast crisis express high levels of bcl-2 (Delia et al. 1992). Whether this is caused by a deregulated c-myb gene or simply reflects their immature stage of differentiation is unclear. In the light of the observed v-Myb-induced protection of myeloid cells from apoptosis under conditions of growth factor deprivation it seems worth reexamining individual cultures of human myeloid leukemias for their response to cytokine starvation.

Does the proposed function of $\mathrm{V}-\mathrm{My} b$ reflect the activity of cellular Myb proteins?

Several indirect lines of evidence suggest that $\mathrm{v}-\mathrm{Myb}$ may mimic an antiapoptotic function of c-Myb in myeloid cells. Thus, immature myelomonocytic cells express high levels of both c-myb (Gonda and Metcalf 1984; Kastan et al. 1989) and bcl-2 (Quéva et al. 1992), and these genes are downregulated as the cells mature (Kastan et al. 1989; Delia et al. 1992). Neutrophils, which are known to have a short life span due to their propensity to die by apoptosis, can be prevented from dying by overexpression of $b c l-2$ (Lagasse and Weissman 1994). Similarly, we have observed that the presence or absence of constitutively expressed $b c l-2$ in ts21-transformed myeloblasts shifted to $42^{\circ} \mathrm{C}$ results, respectively, in either the formation of immature granulocytes in addition to monocytic cells or to apoptotic death and monocytic cells. As in our system, differentiated macrophages lack $b c l-2$ expression. This suggests that cells committed to differentiate into granulocytes die by apoptosis because they lose $b c l-2$ and that monocyte/macrophage-type cells survive because they do not require bcl-2 for survival.

The observation that a c-Myb expressing murine retrovirus transforms myelomonocytic cells kept at high cell densities (Ferrao et al. 1995) is also compatible with a myeloid cell survival-inducing function of the protein. In addition, c-Myb overexpression in the avian myeloid line BM2 has been shown to prevent phorbolester-induced apoptosis (Smarda and Lipsick 1994), although in another study, using the murine M1 myeloid cell line, $c-M y b$ was found to accelerate TGF- $\beta$-induced apoptosis (Selvakumaran et al. 1994). Finally, the observation that expression of a dominant negative Myb/Engrailed chimera dramatically increases apoptosis in T-cells (Taylor et al., this issue) indicates that c-Myb has a survivalinducing function in this cell type.

Neither the overexpression nor the dominant-interfering approaches exclude the possibility that other Myb family members play a role in regulating apoptosis. In particular, because B-Myb, like c-Myb, is also expressed in myeloblasts (Golay et al. 1991) and its ectopic expression accelerates TGF- $\beta$ induced apoptosis in the M1 cell line (Bies and Wolff 1995), it might likewise be involved in the regulation of programmed cell death. To resolve the question of whether $\mathrm{c}-\mathrm{Myb}$ indeed promotes the survival and/or life expectancy of myeloid cells under physiological conditions, it will be crucial to reexamine myelopoiesis in both knockout and transgenic mice.

Our inability to show a significant activity of c-Myb on the $b c l-2$ P2 promoter construct (J. Frampton, unpubl.) 
seems to contradict the proposal that, like $\mathrm{v}-\mathrm{Myb}$, it regulates $b c l-2$ expression. However, because c-Myb has been shown to transactivate the $b c l-2 \mathrm{P} 2$ promoter in 3 T3 cells (D. Taylor, P. Badiani, and $\mathrm{K}$. Weston, submitted), it is possible that the QT6 cell line used in our experiments lacks a coactivator necessary for regulation of the gene. That $\mathrm{v}-\mathrm{Myb}$ is more active on the $b c l-2 \mathrm{P} 2$ promoter than $\mathrm{c}-\mathrm{Myb}$ reflects findings made earlier with the mim-1 promoter (Quéva et al. 1992) and might be due to the lack of the negative regulatory domain present in its cellular counterpart (Sakura et al. 1989; Dubendorff et al. 1992). Our results, therefore, suggest that v-Myb-encoding retroviruses have evolved to efficiently evade a cellular mechanism that down-regulates $b c l-2$ expression in myeloid cells as a consequence of $c-M y b$ inactivation. In this view, ts mutants of E26 with a lesion in $\mathrm{v}-\mathrm{Myb}$ might serve as a simple model to study how c-Myb regulates the $b c l-2$ gene.

\section{Materials and methods}

Viruses and virus constructs

The $t s 21$ wild-type E26 have been described previously (Beug et al. 1984). The viruses expressing Myb and Ets as separate proteins also have been described (Metz and Graf 1991b). To achieve expression of Bcl-2 in myeloid cells transformed by the ts 21 virus we constructed a retrovirus that produces a bicistronic mRNA encoding $\mathrm{Myb}^{\text {ts }}$-Ets and Bcl-2. The basic retroviral structure was derived from pMI3, which contains the gagmyb-ets sequences between AEV LTRs (Introna et al. 1990). A PvulI fragment from the plasmid pCITE2a (Novagen) containing the EMC virus IRES (Jang et al. 1988) and a multiple cloning site was inserted immediately $3^{\prime}$ to the termination codon of the fusion protein at a unique $K p n I$ site. To generate a Bcl-2 expressing virus a $0.7-\mathrm{kb} E c o \mathrm{RI}-S s p \mathrm{I}$ fragment from the chicken $b c l-2$ cDNA was subcloned from the plasmid pIBI-31 /Cazals-Hatem et al. 1992/ into pBluescript-KS between the EcoRI site and a blunt-ended BamHI site. This was subsequently shuttled into the polylinker $3^{\prime}$ of the IRES element between the NcoI and $X b a I$ sites, using the $N c o I$ at the $b c l-2$ ATG codon.

\section{Constructs used in transient transfection assays}

The $b c l-2 / \mathrm{P} 2$ reporter plasmid was derived from the $\mathrm{pXP} 1$ promoterless luciferase vector (deWet et al. 1987) into which we cloned a PCR amplified fragment of the chicken $b c l-2$ gene from residues -303 to -1 (Eguchi et al. 1992). The $5^{\prime}$ and $3^{\prime}$ oligonucleotides used to PCR amplify this region were $5^{\prime}-\mathrm{GAG}^{-}$ GAAGCGTTGCTCAAGT-3' and 5'-GGTTTCCGAGGGGAAGCA-3'. An equivalent fragment mutated at the four consensus MREs was inserted to generate the $b c l-2 / \mathrm{P} 2$ Mut reporter. Mutation was achieved by PCR using the oligonucleotides 5'-GCAACAGTCATAATCCAGTCAAGGTGTGG-3' (sites $1+2$ ), 5' -TAAAATTAAGAACGGCGACAGT-3' (site 3) and $5^{\prime}$-AAGCAGCCGACGGTAATAAA-3' (site 4 ) in which the underlined residues are the mutated sites in the MREs (boldface). The mim-1-luciferase control reporter construct has been described (Ness et al. 1989).

Most of the plasmids encoding the Myb activator proteins have been described previously: Myb-Ets (pMI3; Introna et al. 1990), Myb (pMI10; Introna et al. 1990), and MybVP16 (Frampton et al. 1993). A vector control was constructed from pMI3 by removal of all sequences between the retroviral LTRs by digestion with SstI followed by religation ( $\mathrm{pMI} 3 \Delta \mathrm{X} ; \mathrm{F}$. Lim, unpubl.).

QT6 quail fibroblasts were transfected with reporter and activator constructs by calcium phosphate coprecipitation. Cells $\left(3 \times 10^{5}\right)$ were transfected with $500 \mathrm{ng}$ of the reporter and variable amounts of the activator. Additionally $250 \mathrm{ng}$ of an RSV LTR- $\beta$-galactosidase construct was included as an internal control. Cell extracts were made and assayed for luciferase and $\beta$-galactosidase activities after 2 days. All values were normalized for $\beta$-galactosidase activity.

\section{DNAseI protection assay for in vitro DNA-protein binding}

A HindIII-Xbal fragment derived from the $b c l-2 / \mathrm{P} 2-$ luciferase construct was labeled by fill-in with Klenow polymerase in the presence of $\left[\alpha-{ }^{32} \mathrm{P}\right] \mathrm{dCTP}$. Further digestion was performed with BamHI to generate a 480 -bp fragment labeled at the promoterproximal end. DNAseI footprinting was carried out using standard procedures (Sambrook et al. 1989).

The Myb protein used in the footprinting analysis was obtained following transformation of bacterial strain BL21(DE3) with the pET-Myb5' construct (F. Lim, unpubl.), containing c-Myb coding sequences up to the carboxyl terminus of the DNA binding domain. Colonies were grown to exponential phase and then induced for $3 \mathrm{hr}$ by the addition of $1 \mathrm{~mm}$ isopropyl- $\beta$-D-thiogalactopyranoside (IPTG). To prepare proteins the bacteria were pelleted, resuspended, and sonicated in one volume of $10 \mathrm{~mm}$ HEPES at $\mathrm{pH} 7.9$ and $100 \mathrm{~mm} \mathrm{KCl}$. After centrifugation, the pellet material was resuspended in one volume of STED ( $40 \mathrm{~mm}$ Tris- $\mathrm{HCl}$ at $\mathrm{pH} 7.4,0.25 \mathrm{~mm}$ EDTA, $1 \mathrm{~mm}$ DTT, and $25 \%$ sucrose). Proteins in the pellet, which consisted of up to $50 \%$ of $\mathrm{Myb}$, were denatured by adding urea to a concentration of $4 \mathrm{M}$ at $4^{\circ} \mathrm{C}$ for $30 \mathrm{~min}$. The solubilized denatured proteins were renatured by dialysis against STED and $1 \mathrm{M}$ urea and then STED.

\section{Cell culture and transformation assays}

Chicken cells were obtained from 2-day-old blastoderms of a White Leghorn flock (Lohmann, Cuxhaven). Blastoderm medium consisted of DMEM, $10 \%$ fetal calf serum, $2.5 \%$ chicken serum, $0.2 \% \mathrm{NaHCO}_{3}, 56 \mu \mathrm{g} / \mathrm{ml}$ conalbumin, $80 \mathrm{~mm} \beta$-mercaptoethanol, and $0.9 \mu \mathrm{g} / \mathrm{ml}$ insulin. Unless otherwise indicated, all cells were maintained at $37^{\circ} \mathrm{C}$ in $5 \% \mathrm{CO}_{2}$. Production of virus stocks and the generation of transformed myeloblasts and MEPs by infection of 2-day-old chick embryos has been described previously (Graf et al. 1992). Myeloblast colonies were grown in DMEM containing $10 \mathrm{~mm}$ HEPES, $8 \%$ fetal calf serum, $2 \%$ chicken serum, and 10 units/ml cMGF (Leutz et al. 1984), whereas MEPs were maintained in blastoderm medium (see above).

\section{Cytological and flow cytometric characterization of cells}

To visualize the morphology of individual transformed colonies, cells were subjected to cytocentrifugation and stained with a version of the May Grünwald-Giemsa protocol (Diff Quik, Harleco). To determine the extent of apoptosis cells were pelleted and resuspended in $100 \mathrm{ng} / \mathrm{ml}$ Hoechst 33258 in PBS. Staining of apoptotic cells with dUTP-FITC was done on cytospin preparations using a modification (Sgonc et al. 1994) of the TUNEL method (Gavrieli et al. 1992). Proliferation of cells was determined by incorporation of ${ }^{3} \mathrm{H}$-thymidine into newly synthesized DNA as described previously (Beug et al. 1984). To determine DNA content, cells were fixed in $70 \%$ ethanol, pelleted, and resuspended in $50 \mathrm{~mm}$ sodium citrate, $0.1 \mathrm{mg} / \mathrm{ml}$ RNaseA, and $0.01 \mathrm{mg} / \mathrm{ml}$ propidium iodide. Following incuba- 
tion at $37^{\circ} \mathrm{C}$ for $2 \mathrm{hr}$ the stained cells were analyzed on a FACScan flow cytometer (Becton Dickinson) using Consort software.

To measure the proportion of cells undergoing $S$ phase, cells were labeled for a defined time with $20 \mu \mathrm{M}$ BrdU and then pelleted and fixed in $70 \%$ ethanol for $15 \mathrm{~min}$ at room temperature. The genomic DNA was denatured by incubation of the fixed cells in $0.5 \mathrm{ml} 1 \mathrm{~N} \mathrm{HCl}$ and $0.5 \%$ Tween 20 at $37^{\circ} \mathrm{C}$ for $15 \mathrm{~min}$. After washing twice in $1 \mathrm{ml}$ ice-cold PBS and $1 \%$ BSA the cell pellet was resuspended in $50 \mu \mathrm{l}$ anti-BUdR monoclonal antibody (Partec) diluted 1:50 in PBS and 0.1\% Triton X-100. After 20 min on ice followed by one wash in PBS and $1 \%$ BSA, bound anti-BUdR was detected by incubating the cells in $50 \mu \mathrm{l}$ 1:40 diluted goat antimouse Ig-FITC for $30 \mathrm{~min}$ on ice. The cells were washed and then analyzed by flow cytometry in the presence of propidium iodide as described above.

\section{Isolation and analysis of RNA}

RNA was isolated and processed as described previously (Chomczynski and Sacchi 1987). Total RNA was fractionated on $0.8 \%$ agarose-MOPS-formaldehyde gels, blotted onto Nylon membrane (Hybond-N, Amersham) and probed under high stringency conditions with ${ }^{32} \mathrm{P}$-labeled, randomly primed fragments as described in standard protocols (Sambrook et al. 1989).

The probes used were as follows: Chicken $b c l-2$ cDNA was a 2.2-kb EcoRI fragment from clone pIBI-31 (Eguchi et al. 1992); chicken mim-1 cDNA was a 1-kb EcoRI fragment from clone pMiml (Ness et al. 1989); chicken c-fms (kind gift of U. Fuhrmann, European Molecular Biology Laboratory, Heidelberg, Germany); and chicken $\beta$-actin cDNA was a $1-\mathrm{kb}$ HindIII fragment.

\section{Western blotting}

A crude protein lysate was prepared from $1 \times 10^{6}$ cells by incubation for 30 mins on ice in lysis buffer $(250 \mathrm{~mm} \mathrm{NaCl}, 50 \mathrm{mM}$ Tris- $\mathrm{HCl}$ at $\mathrm{pH} 7.4,1 \mathrm{~mm}$ EDTA, $0.1 \%$ Triton $\mathrm{X}-100$, and protease inhibitors). After clearing by centrifugation the supernatant was adjusted to $1 \times$ protein gel sample buffer, electrophoresed on a $10 \%$ SDS-polyacrylamide gel and transferred to Immobilon membrane (Amersham). Blocking of unspecific reactions, antibody binding, and development of the blot by the ECL technique were as described by the manufacturer.

\section{Acknowledgments}

We thank Suzanne Cory and Yutaka Eguchi for the human and chicken $b c l-2$ cloned sequences, respectively; and Eric Nigg and Subrata Haldar for antibodies against $\mathrm{Cdc} 2$ and $\mathrm{Bcl}-2$. We are also grateful to Filip Lim for various unpublished retroviral and protein expression constructs. Finally we would like to thank Carmela Calés, Anne Ephrussi, and Patricia Kahn for critical reading of the manuscript and members of the Graf lab for numerous discussions.

The publication costs of this article were defrayed in part by payment of page charges. This article must therefore be hereby marked "advertisement" in accordance with 18 USC section 1734 solely to indicate this fact.

\section{References}

Athanasiou, M., G.J. Mavrothalassitis, C.C. Yuan, and D.G. Blair. 1996. The Gag-Myb-Ets fusion oncogene alters the apoptotic response and growth factor dependence of interleukin-3 dependent murine cells. Oncogene 12: 337-344.

Beug, H., M.J. Hayman, and T. Graf. 1982. Myeloblasts transformed by the avian acute leukemia virus E26 are hormone- dependent for growth and for the expression of a putative myb-containing protein, p135 E26. EMBO J. 1: 1069-1073.

Beug, H., A. Leutz, P. Kahn, and T. Graf. 1984. Ts mutants of E26 leukemia virus allow transformed myeloblasts, but not erythroblasts or fibroblasts to differentiate at the nonpermissive temperature. Cell 39: 579-588.

Beug, H., P. Blundell, and T. Graf. 1987. Reversibility of differentiation and proliferative capacity in avian myelomonocytic cells transformed by $t s E 26$ leukemia virus. Genes \& Dev. 1: 277-286.

Bies, J. and L. Wolff. 1995. Acceleration of apoptosis in transforming growth factor beta 1-treated M1 cells ectopically expressing B-myb. Cancer Res. 55: 501-504.

Burk, O., S. Mink, M. Ringwald, and K.-H. Klempnauer. 1993. Synergistic activation of the chicken mim-1 gene by v-myb and C/EBP transcription factors. EMBO J. 12: 2027-2038.

Cazals-Hatem, D.L., D.C. Louie, S. Tanaka, and J.C. Reed. 1992. Molecular cloning and DNA sequence analysis of cDNA encoding chicken homologue of the Bcl-2 oncoprotein. Biochem. Biophys. Acta. 1132: 109-113.

Chomczynski, P. and N. Sacchi. 1987. Single-step method of RNA isolation by acid guanidinium thiocyanate-phenolchloroform extraction. Anal. Biochem. 162: 156-159.

deWet, J.R., K.V. Wood, M. DeLuca, D.R. Helsinki, and S. Subramani. 1987. Firefly luciferase gene: Structure and expression in mammalian cells. Mol. Cell. Biol. 7: 725-737.

Delia, D., A. Aiello, D. Soligo, E. Fontanella, C. Melani, F. Pez zella, M.A. Pierotti, and G.D. Porta. 1992. bcl-2 proto-oncogene expression in normal and neoplastic human myeloid cells. Blood 79: 1291-1298.

Dubendorff, J.W., L.J. Whittaker, J.T. Eltman, and J.S. Lipsick. 1992. Carboxy-terminal elements of c-Myb negatively regulate transcriptional activation in cis and in trans. Genes \& Dev. 6: 2524-2535.

Eguchi, Y., D.L. Ewert, and Y. Tsujimoto. 1992. Isolation and characterization of the chicken $b c l-2$ gene: Expression in a variety of tissues including lymphoid and neuronal organs in adult and embryo. Nucleic Acids Res. 20: 4187-4192.

Evan, G.I., A.H. Wyllie, C.S. Gilbert, T.D. Littlewood, H. Land, M. Brooks, C.M. Waters, L.Z. Penn, and D.C. Hancock. 1992. Induction of apoptosis in fibroblasts by c-myc protein. Cell 69:119-128.

Fairbairn, L.J., G.J. Cowling, B.M. Reipert, and T.M. Dexter. 1993. Suppression of apoptosis allows differentiation and development of a multipotent hemopoietic cell line in the absence of added growth factors. Cell 74: 823-832.

Ferrao, P., E.M. Macmillan, L.K. Ashman, and T.J. Gonda. 1995. Enforced expression of full length c-Myb leads to densitydependent transformation of murine haematopoietic cells. Oncogene 11: 1631-1638.

Frampton, J. and T. Graf. 1996. Myb proteins: Regulators of haemopoietic cell growth, differentiation and apoptosis. In Transcription factors in eukaryotes (ed. A.G. Papavassiliou) R.G. Landes, Austin, TX.

Frampton, J., T. Kouzarides, G. Döderlein, T. Graf, and K. Weston. 1993. Influence of the $\mathrm{v}-\mathrm{Myb}$ transactivation domain on the oncoprotein's transformation specificity. EMBO J. 12: 1333-1341.

Frampton, J., K.M. McNagny, M. Sieweke, A. Philip, G. Smith, and T. Graf. 1995. v-Myb DNA binding is required to block thrombocytic differentiation of Myb-Ets-transformed multipotent haematopoietic progenitors. $E M B O \quad J$. 14: 28662875.

Frykberg, L., T. Metz, G. Brady, M. Introna, H. Beug, B. Vennström, and T. Graf. 1988. A point mutation in the DNA binding domain of the $v-m y b$ oncogene of E26 virus confers 
temperature sensitivity for transformation of myelomonocytic cells. Oncogene Res. 3: 313-322.

Gavrieli, Y., Y. Sherman, and S.A. Ben-Sasson. 1992. Identification of programmed cell death in situ via specific labeling of nuclear DNA fragmentation. J. Cell Biol. 119: 493-501.

Golay, J., M. Introna, and T. Graf. 1988. A single point mutation in the v-ets oncogene affects both erythroid and myelomonocytic cell differentiation. Cell 55: 1147-1158.

Golay, J., A. Capucci, M. Arsura, M. Castellano, V. Rizzo, and M. Introna. 1991. Expression of c-myb and B-myb, but not A-myb, correlates with proliferation in human hematopoietic cells. Blood 77: 149-158.

Gonda, T.J. and D. Metcalf. 1984. Expression of myb, myc and fos proto-oncogenes during the differentiation of a murine myeloid leukaemia. Nature 310: 249-251.

Graf, T. 1973. Two types of target cells for transformation with avian myelocytomatosis virus. Virology 54: 398-413.

Graf, T. 1992. Myb: A transcriptional activator linking proliferation and differentiation in hematopoietic cells. Curr. Opin. Genet. Dev. 2: 249-255.

Graf, T., K.M. McNagny, G. Brady, and J. Frampton. 1992. Chicken "erythroid" cells transformed by the Gag-myb-ets encoding E26 leukemia virus are multipotent. Cell 70: 201213.

Ham, J., C. Babij, I. Whitfield, C.M. Pfarr, D. Lallemand, M. Yaniv, and L.L. Rubin. 1995. A c-Jun dominant negative mutant protects sympathetic neurons against programmed cell death. Neuron 14: 927-939.

Introna, M., J. Golay, J. Frampton, T. Nakano, S.A. Ness, and T. Graf. 1990. Mutations in $v-m y b$ alter the differentiation of myelomonocytic cells transformed by the oncogene. Cell 63: $1287-1297$

Jang, S.K., H.-G. Krausslich, M.J.H. Nicklin, G.M. Duke, A.C. Palmenberg, and E. Wimmer. 1988. A segment of the $5^{\prime}$ nontranslated region of encephalomyocarditis virus RNA directs internal ribosome entry of ribosomes during in vitro translation. J. Virol. 62: 2636-2643.

Kastan, M.B., K.D. Stone, and C.I. Civin. 1989. Nuclear oncoprotein expression as a function of lineage, differentiation stage, and proliferation status of normal human hematopoietic cells. Blood 74: 1517-1524.

Kitada, S., T. Miyashita, S. Tanaka, and J.C. Reed. 1993. Investigations of antisense oligonucleotides targeted against bcl-2 RNAs. Antisense Res. Dev. 3: 157-169.

Kraut, N., J. Frampton, K.M. McNagny, and T. Graf. 1994. A functional Ets DNA-binding domain is required to maintain multipotency of hematopoietic progenitors transformed by Myb-Ets. Genes \& Dev. 8: 33-44.

Lagasse, E. and I.L. Weissman. 1994. bcl-2 inhibits apoptosis of neutrophils but not their engulfment by macrophages. $I$. Exp. Med. 179: 1047-1052.

Leutz, A., H. Beug, and T. Graf. 1984. Purification and characterization of cMGF, a novel chicken meyelomonocytic growth factor. EMBO I. 3: 3191-3197.

Lucas, A. and C. Jamroz. 1961. Atlas of avian hematology. Monograph of the United States Department of Agriculture, Washington, DC.

Lüscher, B. and R.N. Eisenman. 1990. New light on MYC and MYB. Part II. MYB. Genes \& Dev. 4: 2235-2241.

Metz, T. and T. Graf. 1991a. Fusion of the nuclear oncoproteins $\mathrm{v}-\mathrm{Myb}$ and $\mathrm{v}$-Ets is required for the leukemogenicity of E26 virus. Cell 66: 95-105.

- 1991b. v-myb and v-ets transform chicken erythroid cells and cooperate both in trans and in cis to induce distinct differentiation phenotypes. Genes \& Dev. 5: 369-380.

Metz, T., T. Graf, and A. Leutz. 1991. Activation of cMGF ex- pression is a critical step in avian myeloid leukemogenesis. EMBO J. 10: 837-844.

Miyashita, T. and J. Reed. 1995. Tumor suppressor p53 is a direct transcriptional activator of the human bax gene. Cell 80: 293-299.

Miyashita, T., M. Harigai, M. Hanada, and J.C. Reed. 1994a. Identification of a p53-dependent negative response element in the bcl-2 gene. Cancer Res. 54: 3131-3135.

Miyashita, T., S. Krajewski, M. Krajewska, H.G. Wang, H.K. Lin, D.A. Liebermann, B. Hoffman, and J.C. Reed. 1994b. Tumor suppressor p53 is a regulator of $b c l-2$ and bax gene expression in vitro and in vivo. Oncogene 9: 1799-1805.

Mucenski, M.L., K. McLain, A.B. Kier, S.H. Swederlow, C.M. Schreiner, T.A Miller, D.W. Pietryga, W.J. Scott, Jr., and S.S. Potter. 1991. A functional c-myb gene is required for normal murine fetal hepatic hematopoiesis. Cell 65: 677-689.

Negrini, M., E. Silini, C. Kozak, Y. Tsujimoto, and C.M. Croce. 1987. Molecular analysis of $\mathrm{mbcl}-2$ : Structure and expression of the murine gene homologous to the human gene involved in follicular lymphoma. Cell 49: 455-463.

Ness, S.A., A. Marknell, and T. Graf. 1989. The $v-m y b$ oncogene product binds to and activates the promyelocytic-specific mim-1 gene. Cell 59: 1115-1125.

Ness, S.A., E. Kowenz-Leutz, T. Casini, T. Graf, and A. Leutz. 1993. Myb and NF-M: Combinatorial activators of myeloid genes in heterologous cell types. Genes \& Dev. 7: 749-759.

Quéva, C., S.A. Ness, F.A. Grässer, T. Graf, B. Vandenbunder, and D. Stéhelin. 1992. Expression patterns of $c-m y b$ and of $v$-myb induced myeloid-1 (mim-1) gene during the development of the chick embryo. Development 114: 125-133.

Radke, K., H. Beug, S. Kornfeld, and T. Graf. 1982. Transformation of both erythroid and myeloid cells by E26, an avian leukemia virus that contains the myb gene. Cell 31: 643653

Reddy, M.A., B.S. Yang, X. Yue, C.J. Barnett, I.L. Ross, M.J. Sweet, D.A. Hume, and M.C. Ostrwski. 1994. Opposing actions of c-ets/PU.l and c-myb protooncogene products in regulating the macrophage-specific promoters of the human and mouse colony-stimulating factor-1 receptor (c-fms genes). J. Exp. Med. 180: 2309-2319.

Roussel, M., S. Saule, C. Lagrou, C. Rommens, H. Beug, T. Graf, and D. Stehelin. 1979. Three new types of viral oncogene of cellular origin specific for haematopoietic cell transformation. Nature 281: 452-455.

Sakura, H., C. Kanei-Ishii, T. Nagase, H. Nakagoshi, T.J. Gonda, and S. Ishii. 1989. Delineation of three functional domains of the transcriptional activator encoded by the c-myb protooncogene. Proc. Natl. Acad. Sci. 86: 5758-5762.

Sambrook, J., E.F. Fritsch, and T. Maniatis. 1989. Molecular cloning: A laboratry manual, 2nd edition. Cold Spring Harbor Laboratory Press, Cold Spring Harbor, NY.

Selvakumaran, M., H.K. Lin, R.T. Sjin, J.C. Reed, D.A. Liebermann, and B. Hoffman. 1994. The novel primary response gene MyDl 18 and the proto-oncogenes myb, myc, and bcl-2 modulate transforming growth factor beta 1 -induced apoptosis of myeloid leukemia cells. Mol. Cell. Biol. 14: 23522360.

Seto, M., U. Jaeger, R.D. Hockett, W. Graninger, S. Bennett, P. Goldman, and S.J. Korsmeyer. 1988. Alternative promoters and exons, somatic mutation and deregulation of the $\mathrm{Bcl}-2$. Ig fusion gene in lymphoma. EMBO I. 7: 123-131.

Sgonc, S., G. Boeck, H. Dietrich, J. Gruber, H. Recheis, and G. Wick. 1994. Simultaneous determination of cell surface antigens and apoptosis. Trends Genet. 10: 41-42.

Shapiro, L.H. 1995. Myb and Ets proteins cooperate to transactivate an early myeloid gene. J. Biol. Chem. 270: 8763-8771. 
Shen-Ong, G.L.C. 1990. The myb oncogene. Biochim. Biophys. Acta. 1032: 39-52.

Sieweke, M., H. Tekotte, J. Frampton, and T. Graf. 1996 . MafB is an interaction partner and repressor of Ets-1 that inhibits erythroid differentiation. Cell 85: 49-60.

Smarda, I. and J.S. Lipsick. 1994. c-Myb prevents TPA-induced differentiation and cell death in v-Myb transformed monoblasts. Oncogene 9: 237-245.

Taylor, D., P. Badiani, and K. Weston. 1996. A dominant interfering Myb mutant causes apoptosis in T cells. Genes \& Dev. (this issue).

Westin, E.H., R.C. Gallo, S.K. Arya, A. Eva, L.M. Souza, M.A. Baluda, S.A. Aaronson, and F. Wong-Staal. 1982. Differential expression of the amv gene in human hematopoietic cells. Proc. Natl. Acad. Sci. 79: 2194-2198.

Weston, K. 1992. Extension of the DNA binding domain consensus of the chicken $\mathrm{c}-\mathrm{Myb}$ and $\mathrm{v}-\mathrm{Myb}$ proteins. Nucleic Acids Res. 20: 3043-3049.

White, D.W., A. Roy, and T.D. Gilmore. 1995. The v-Rel oncoprotein blocks apoptosis and proteolysis of I kappa B-alpha in transformed chicken spleen cells. Oncogene 10: 857-868.

Young, R.L. and S.J. Korsmeyer. 1993. A negative regulatory element in the $b c l-25^{\prime}$-untranslated region inhibits expression from an upstream promoter. Mol. Cell. Biol. 13: 36863697 . 


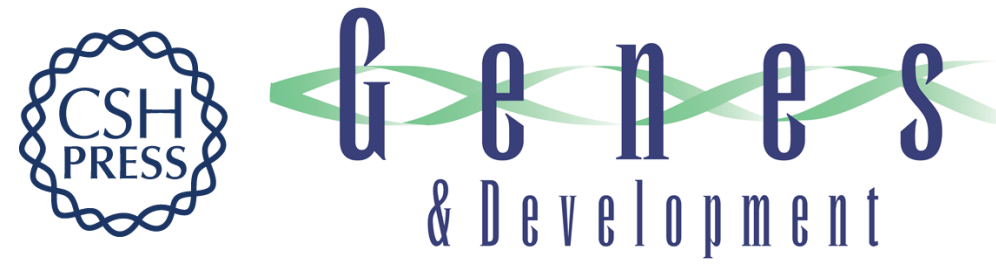

\section{v-Myb of E26 leukemia virus up-regulates bcl-2 and suppresses apoptosis in myeloid cells.}

J Frampton, T Ramqvist and T Graf

Genes Dev. 1996, 10:

Access the most recent version at doi:10.1101/gad.10.21.2720

References This article cites 60 articles, 22 of which can be accessed free at:

http://genesdev.cshlp.org/content/10/21/2720.full.html\#ref-list-1

License

Email Alerting

Service

Receive free email alerts when new articles cite this article - sign up in the box at the top right corner of the article or click here.

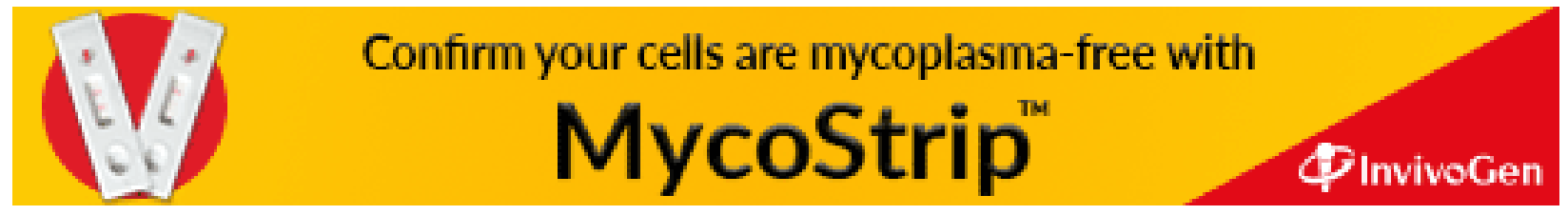

